Stanislaw Grodziski

(Kraków)

\title{
Czarna księga Wiśnicza
}

\section{Schwarzes Buch von Wiśnicz}

1. Działalność edytorska pod patronatem PAN. 2. Acta maleficorum Wiśniciae. 3. Sąd w Wiśniczu.

1. Verlagstätigkeit unter dem Patronat von PAN. 2. Acta maleficorum Wisniciae. 3. Gericht von Wiśnicz.

Podstawę dla poniższych rozważań dało jedno wydawnictwo zasługujące na uwage zarówno ze względu na swój wysoki poziom, jak i z powodu charakteru materiału źródłowego: Ksiega zloczyńców sqqu kryminalnego w Wiśniczu (1629-1665). Nie zamierzam tu jednak wyłącznie pisać recenzji, na którą skądinąd wydawnictwo to w pełni zasługuje.

Warto przypomnieć, iż kiedy powstała w 1952 r. Polska Akademia Nauk, w ramach jej Komitetu Nauk Prawnych powołana została do życia Komisja Wydawnictw Źródłowych, pod przewodnictwem prof. Adama Vetulaniego. W miejsce zasłużonych wydawnictw Polskiej Akademii Umiejętności (Starodawne prawa polskiego pomniki, Archiwum Komisji Prawniczej) utworzono wspólną serię pod nazwą Pomniki prawa polskiego, a w jej ramach - trzy działy poświęcone prawu ziemskiemu, miejskiemu i wiejskiemul. Ukazywały się $w$ tej serii - niemal rok za rokiem - cenne wydawnictwa, zwłaszcza osiem tomów ksiąg sądowych wiejskich obejmujących material praktyki sądowej od XV do końca XVIII w. Wypracowane zostały i wprowadzone w praktyce szczególowe zasady wydawnicze ${ }^{2}$.

Po upływie dwudziestu lat działalność edytorska osłabła. Pomniki przeniesione zostały z Komitetu Nauk Prawnych do Instytutu Historii PAN,

\footnotetext{
${ }^{1}$ Por. Przeglad prac prowadzonych w ramach Komitetu Nauk Prawnych PAN nad wydawnictwami źródlowymi, Czasopismo Prawno-Historyczne 1953 [dalej: CPH], t. 5, s. 336-327.

${ }^{2} \mathrm{~A}$. Vetulani, W sprawie zasad wydawniczych materialu zapiskowego, CPH 1959, t. XI, z. 1, s. 157-165, Por. też recenzję W. Hejnosza z wydawnictwa A. Vetulaniego, Ksiega sqdowa Uszwi dla wsi Zawady 1619-1788, CPH 1958, 1. X, z. 1, s. 210-213.
} 
następnie - chociaż przygotowanego już do dalszej działalności wydawniczej materiału źródłowego nie brakowało ${ }^{3}$ - dotknęły je restrykcje finansowe. Przestały się ukazywać nie z merytorycznych względów, bo ich wartość naukowa byla poważna, ale z powodów czysto oszczędnościowych. Próbowano jeszcze nawiązywać do tej serii, ale jej ożywienie już się nie powiodło ${ }^{4}$. Nie ulega też wątpliwości, że osłabło zainteresowanie naukowe źródłami dotyczącymi - jak to formułowano w doktrynie marksistowskiej - bezpośrednich wytwórców dóbr materialnych.

Wprawdzie pod kierunkiem Adama Vetulaniego powstał silny zespół edytorski, ale upływ czasu przerzedzal jego szeregi. Istotne skutki odniósł także dość szczególny stosunek władz oraz środowiska naukowego jako całości do pracy edytorskiej: najcenniejsze choćby wydawnictwo źródłowe nie stanowiło ani nie stanowi podstawy do przewodu doktorskiego lub habilitacyjnego i nie zmienia tego fakt, że edycje źródłowe są znacznie trwalsze od monografii - nie starzeją się szybko i służą dobrze nauce przez kilka pokoleń. Wszystko to nie sprzyja podejmowaniu pracy edytorskiej przez młodych pracowników naukowych, powoduje porzucanie jej przez starszych.

Pozostał jednak przy tej pracy najmłodszy z uczniów Adama Vetulaniego - Waclaw Uruszczak. W jego opracowaniu ukazało się drukiem wydawnictwo: Acta Maleficorum Wiśniciae (1629-1665). Ksiega zloczyńców sqdu kryminalnego w Wiśniczu (1629-1665) (Collegium Columbinum, Biblioteka Tradycji, nr XXVIII Kraków 2003, s. $371+10$ nlb). Jest to tak zwana czarna ksiega, czyli szczególny typ księgi sądowej, zawierająca zapiski spraw karnych, $\mathrm{z}$ reguły dotyczących zbrodni. Wartość badawcza - jak słusznie to podkreślił Wydawca we Wprowadzeniu - jest znaczna.

Wydawnictwo to składa się ze zwięzłego wstępu, czyli Wprowadzenia (s. 7-14) oraz tekstu źródłowego (s. 15-295) i zostało zaopatrzone w lacińskopolski słowniczek ważniejszych terminów prawnych (s. 297-301), wreszcie indeksy nazw geograficznych, imion i nazwisk oraz rzeczowy (s. 303-371). W pracy nad aparatem naukowym dopomagali Wydawcy: Irena Dwornicka, Marta Kusznierewicz-Mikś, Bartlomiej Migda i Adam Uruszczak.

${ }^{3}$ Omówiła to I. Dwornicka, Teki Adama Vetulaniego, Rocznik Biblioteki PAN w Krakowie 1999, t. XLIV, s. 77 i n.

${ }^{4}$ Kiedy w 1978 r. ukazywała się drukiem Ksiega sqdowa państwa żywieckiego 1681-1773 (opr. M. Karaś i L. Lysiak), merytorycznie jak najbardziej zaliczająca się do serii ksiąg sądowych wiejskich, nie było już możliwości wydania jej w ramach Pomników prawa polskiego. Ukazała się więc wydaniem Zeszytów Naukowych UJ [Warszawa-Kraków] 1978, Prace językoznawcze, nr 57. Zadbano tylko o szatę zewnętrzną nawiązującą do serii ksiąg sądowych wiejskich. 
Krokiem naprzód ku nowoczesności jest dołączenie do wydawnictwa płyty $\mathrm{CD}$ zawierającej pełną podobiznę rękopisu. Czytelnik, wyświetliwszy płytę w komputerze, może ocenić ogrom drobiazgowej pracy, jaka została włożona w odczytanie zniszczonego, pełnego luk i uszkodzeń rękopisu, lub też, w razie wątpliwości, porównać sobie odczytany w wydawnictwie tekst $\mathrm{z}$ fotokopią. Sięganie do rękopisu - zetlałego i przez samo czytanie ulegającego uszkodzeniom, stało się rzeczą zbędną.

Sądowi w Wiśniczu, jego szczególnemu znaczeniu i wielkiemu rozgłosowi należy się bliższa uwaga; zasługuje on nawet na odrębną monografię. Już bowiem w parę lat po lokacji miasteczka Nowego Wiśnicza działał ów sąd - jak tego dowodzi omawiana ta Ksiega zloczyńców - sprawnie. Wyspecjalizowal się zwłaszcza $w$ postępowania inkwizycyjnym $w$ zakresie spraw karnych, co czyniło go podobnym do sądów rugowych. Wiśnicz uzyskał prawo miecza, utrzymywal kata (zwanego zwykle egzekutorem), który przeprowadzał zlecone mu przez sąd tortury, wykonywał wyroki śmierci.

Musiała zatem istnieć lokalna tradycja sięgająca czasów, kiedy Wiśniczem władali Kmitowie herbu Śreniawa. Zbudowali oni w XIV w. gródek, który w wieku XVI stal się pięknym, renesansowym zamkiem, nieraz goszczącym monarchę i najwyższych dostojników Korony. Zamek ten zakupił w $1593 \mathrm{r}$. Sebastian Lubomirski (ok. 1546-1613) - żupnik krakowski i kasztelan wojnicki. Ten fundator potęgi rodu był już pod koniec swego życia wlaścicielem około osiemdziesięciu wsi rozrzuconych po Ziemi Krakowskiej, na Podhalu i w Sądecczyźnies. Jego syn Stanisław (1583-1649) - wojewoda krakowski, starosta spiski, bohater spod Chocimia - przebudowal zamek w Wiśniczu i założyl miasto Nowy Wiśnicz; stało się to $w$ roku 1622 , na kilka lat przed datą, od której zaczynają się zapiski Ksiegi zloczyńców. Ufundował w swym mieście klasztor Karmelitów (jako votum za zwycięstwo pod Chocimiem 1621 r., gdzie dowodził po śmierci Hetmana Chodkiewicza), zbudował ratusz miejski. On też poszerzył latyfundium, które łącznie z kolebką rodu - Lubomierzem w powiecie szczyrzyckim - sięgało od Wisty i Krakowa, aż po Spisz i Tatry.

Przed lokacją miasta zamek Wiśnicz był zapewne siedzibą sądu dominialnego, który rozpatrywał sprawy także i z dalej położonych dóbr Lubomirskich. Prawdopodobnie ich rządcy czy ekonomowie, kiedy któryś z poddanych popełnił przestępstwo zagrożone karą gardła, odsyłali obwinionego w kajdanach $\mathrm{i}$ pod strażą do zamku. Zamek, palazzo in fortezza czyli mocno ufortyfikowany,

${ }_{5}^{5}$ Por. jego biogram pióra J. Długosza, PSB, t. XVIII, s. 40-42.
${ }^{6}$ Por. jego biogram pióra W. Czaplińskiego, ibidem, s. 42-45. 
dysponował kazamatami nadającymi się na więzienie ${ }^{7}$. W nich można było poddać obwinionego torturom, a jęki męczonych nie zakłócały życia dworskiego. W Wiśniczu przebywał często „,pan dziedziczny” - Stanisław Lubomirski, i do niego można było kierować apelacje, wnosić ,instancje” o lagodzenie wyroków.

Kiedy założone zostalo miasto Nowy Wiśnicz, wówczas niektóre funkcje sądu dominialnego (zamkowego) przejął sąd miejski. Różnił się on zapewne tylko składem sędziowskim, działającym pod przewodnictwem wójta, gdyż zanim zbudowano $w$ mieście ratusz, sąd miejski działał także w zamku, in castro $^{8}$. Tak wiẹc zarówno tradycja zamkowa, jak i sąsiedztwo Bochni, której rajcy zasiadali w Sądzie sześciu miast, a także królewskiej Lipnicy Murowanej, wpłynęły nie tylko na organizację, ale i poziom sądu wiśnickiego. Niewykluczone jest również, że wzrost znaczenia sądu wiśnickiego wiązał się $\mathrm{z}$ ewolucją Sądu sześciu miast, który tracił na znaczeniu i stawał się sądem o zasięgu lokalnym.

Bliższa uwaga należy się owej organizacji sądu, którą Wydawca Ksiegi zloczyńców omówił zbyt zwięźle (s. 12-13). Był to typowy miejski sąd lawniczy, wlaściwy dla wszystkich spraw wnoszonych przedeń przez mieszkańców Nowego Wiśnicza, działający w zwyczajowo określonych terminach. Prowadził swoje księgi sądowe, w których pisarz miejski zapisywal - jak i w sąsiednich miastach Bochni czy Lipnicy - transakcje kupna-sprzedaży nieruchomości, testamenty, ugody, zobowiązania finansowe ${ }^{9}$. Kiedy jednak do sądu doprowadzano z bliższej czy dalszej okolicy jakiegoś przestępcę, sąd zbierał się dla tej sprawy odrębnie i był to wówczas sqd pilny, z konieczności zagajony (iudicum arduum necessitatis causa bannitum). Tym samym występowal w sądzie wiśnickim w poważnych sprawach karnych podział na jurysdykcję „,normalną” oraz „,nadzwyczajną”. Po tej drugiej pozostały zapiski w postaci „złoczyńców”l0.

Zachowane do dziś zapiski mają charakter indukty, czyli czystopisu. $\mathrm{Na}$ rozprawie, a także podczas postępowania dowodowego $\mathrm{w}$ postaci tortur, pisarz sądowy sporządzał protokól, który potem przepisywano starannie do księgi, zaopatrując go w stosowne lacińskie formuly początkowe i końcowe, poprawiając lub skracając pierwotne sformułowania. Pomimo to $w$ tekście

\footnotetext{
${ }^{7}$ Por. zapiskę 21, s. 96; zapiskę 23, s. 102; zapiskę 33, s. 162 . Kazamaty znajdowały się w otaczających zamek pięciokątem fortyfikacjach. Jedna z czterech wież zamkowych nosiła nazwę tureckiej, co mogło świadczyć, że służyła za pomieszczenie dla jeńców, a może i zwykłych więźniów.

${ }^{8}$ Por. zapiske 7 , s. 41 ; zapiske 9, s. 49 ; zapiske 19 , s. 50.

${ }^{9}$ Po tej działalności sądu pozostał rękopis pt. Liber inscriptionum actionum, causarum [...], ab anno 1622 ad annum 1765, Officium Consulariae Neo-Wisnicensis (Archiwum Państwowe w Krakowie, I. T. nr 2046).

${ }^{10}$ Poza wydaną drukiem Ksiegga zloczyńców, zachował się drugi rękopis, będący kontynuacją poprzedniego: Acta nigra maleficorum Wiśniciae ab anno Domini 1665 legibus et poenia in eisdem sancitis punitorom inchoant (Archiwum Państwowe w Krakowie, I. T. nr 2059).
} 
pozostało wiele autentycznych sformułowan, cytowanych wręcz in extenso wypowiedzi obwinionych i świadków, czasami bardzo interesujących i barwnych $^{11}$.

Wydawca - Wacław Uruszczak - dobrze się przyshużył nauce; po pierwsze, odnalazl rẹkopis Księgi zloczyńców, który - z nieznanych dzisiaj powodów - przechowywany był w Archiwum Diecezjalnym w Tarnowie, podczas gdy podstawowy zasób źródel rękopiśmiennych z Wiśnicza znalazł się w Krakowie ${ }^{12}$. Rękopis ten jest pierwszym tomem wiśnickich zapisek i od niego należalo rozpocząć akcję wydawniczą; Wydawca planuje bowiem w dalszej kolejności edycję rękopisu krakowskiego ${ }^{13}$. Po drugie, rękopis ten skopiowal, skolacjonował $\mathrm{z}$ pomoca językoznawców (a z powodu stanu zniszczenia rękopisu byla to praca bardzo żmudna), opatrzył aparatem naukowym i opublikowal. Edycja oparta na zasadach przyjętych uprzednio w serii wydawniczej ksiąg sądowych wiejskich jest nowoczesna i poprawna ${ }^{14}$.

Do rozważań o wartości badawczej tekstu Ksiegi zloczyńców pragnę dodać pewne uwagi o dalszych losach sądu wiślickiego.

Już z samych zapisek wynika, że ława wiśnicka uzyskała wielkie znaczenie i stała się rychło po lokacji miasta instytucją, znaną w południowej Małopolsce, jako nie tylko sąd miasta Nowego Wiśnicza i nie tylko sąd zamkowy. Stawali przed nią doprowadzani $w$ kajdanach przestępcy $z$ dóbr panów Lubomirskich, ale także $\mathrm{z}$ bliższych i dalszych wsi szlacheckich, kościelnych oraz $\mathrm{z}$ królewszczyzn. Ich właściciele oraz dzierżawcy niechętnie - jak wiadomo - podejmowali się rozpatrywać przed swymi sądami dominialnymi sprawy, które mogły się były zakończyć wyrokiem „na gardle”. Wytworzyla się więc praktyka przekazywania takich spraw sądom grodzkim lub miejskim, i sąd miasta Nowego Wiśnicza pełnił te usługe dla terenów od Wisły po Tatry.

Rychło więc sąd ów budzić począl grozę wśród przestępców, w tym wielu podhalańskich zbójników, którym przyszło przed nim stawaćc ${ }^{15}$. Byli

"Czytamy np. w zapisce nr 5 (s. 30), iż czterech zbójców napadło na dwór w Męcinie (pomiędzy Limanową i Nowym Sączem): Panna nas obaczyla co się kapala $w$ rzece $i$ uciekla do dwora. Pan Krzesz wypadl do nas - a na ten czas jadl, jeszcze ser w reku mial - $i$ zaraz ja nam lajać, a mial kord [...] Po tym rzekl: pocoscie tu przyszli, skurwy synowie. I cial mnie kordem, jam mu się zlożyl siekierkq...

${ }_{12}$ Nie wyjaśnił tego F. Duda - autor pracy: $O$ zabytkach rękopissmiennych gmin zachodnio-galicyjskich, Kraków 1918 (mpis, własność Archiwum państwowego w Krakowie), s. 186-188. Być może dokonał tego założyciel i organizator Muzeum Diecezjalnego, biskup tarnowski Ignacy Lobos.

${ }_{13}$ Por. przyp. 9.

${ }^{14} \mathrm{Z}$ obowiązku recenzenckiego tylko zaznaczę, iż nie jest trafną decyzja, że liczby w indeksach oznaczają numer zapiski i kartę rękopisu, a nie stronę wydawnictwa. Zapewne Wydawca uznał, iż czytelnik będzie się równie często poshugiwał fotokopią rẹkopisu, na płycie CD.

15 Por. zapiskę nr 3, s. 19 i n., dotyczącą bandy zbójeckiej z Dobrej, pomiędzy Mszaną a Tymbarkiem. W zapisce nr 4, s. 25 i n., występuja zbójnicy z Waksmundu i Bystrej koło Nowego Targu oraz zlodzieje $z$ Dobczyc nad Rabą i z okolic. W zapisce nr 6, s. 36-4l, 
to ludzie dalecy od romantycznej legendy, najczęściej prymitywni i okrutni zbrodniarze. Niejasną jest rzeczą, dlaczego ujętych na rozboju w górach nie odsyłano do Nowego Sącza czy Nowego Targu, lecz transportowano ich aż do Wiśnicza. Przypuszczam tylko, iż zadecydowała o tym praktyka sądowa panów Lubomirskich, którym nie przeszkadzala fama, jaka otaczała Wiśnicz. Przestępcy poddawani torturom - najpierw $w$ zamku, potem $w$ ratuszu miejskim - zeznawali szczegółowo, rzadko zachowując milczenie; bezpośrednio po wyroku karani byli śmiercią poprzez ćwiartowanie, ścięcie mieczem lub powieszenie $^{16}$. Nie stosowano $\mathrm{w}$ Wiśniczu wieszania za żebro. W tradycji góralskiej zamek $\mathrm{w}$ Wiśniczu pamiętany był jeszcze $\mathrm{w}$ XIX $\mathrm{w}^{17}$

Znaczenie sądu Nowego Wiśnicza było tak duże, że pełnił on ważną rolę także po zaborze, pod panowaniem austriackim. Kiedy w 1787 r. reorganizowano sądownictwo karne na terenie Galicji, w całej prowincji utworzono dziewiętnaście sądów karnych, po jednym na każdy cyrkul, łącznie z Bukowiną ${ }^{18}$. Choć stolicą miejscowego cyrkułu była Bochnia, sąd działał w Wiśniczu. Po skasowaniu w 1788 r. miejscowego klasztoru Karmelitów, sąd ten wyposażony został $\mathrm{w}$ obszerny lokal oraz dysponował więzieniem - nie używano więc już odtąd $w$ tym celu kazamat zamkowych ani piwnic ratusza. W $1818 \mathrm{r}$. zmniejszono liczbę sądów karnych do sześciu, a sąd w Wiśniczu objął cały zachód Galicji i cyrkuły bocheński, myślenicki i sądecki ${ }^{19}$. Ten system utrzymał się aż do reform $\mathrm{z}$ drugiej połowy XIX w.

Powracając do omawianej tu podstawy źródłowej, należy podkreślić, iż wydawnictwo Ksiegi zloczyńców dobrze przysłuży się nauce, znacznie po-

sądzony był przestępca z Tylmanowej nad Dunajcem oraz z Ochotnicy, gdzie bywalo zbójców po dwadzieścia w kupie. Wspomniane też zostały skarby zbójeckie, rzekomo zakopane na Lubaniu. Zapiska nr 23, s. 102-106, dotyczy przestępcy z Dobrej dżałającego w okolicach Łącka nad Dunajcem. W zapisce nr 33, s. 150-162, występują zbójcy z Kresa Muszyńskiego należącego do biskupstwa krakowskiego, niektórzy tamże już osądzeni; dowodzi to istnienia współpracy miẹdzy sądami w Wiśniczu i Muszynie. Zapiska nr 35, s. 166-176, dotycząca rabusia z Nowej Wsi (miedzy Nowym Sączem a Krynicą) wiązała się też z Kresem Muszyńskim. Zapiska nr 39, s. 195-200, dotyczy sprawy jednego z członków dwunastoosobowej bandy zbójeckiej z Nowej Wsi, Nawojowej i Rostok. Zapiska nr 45, s. 253-285, dotyczy bandy zbójeckiej działającej po obu stronach Karpat, aż po starostwo spiskie, także w dobrach Kresu Muszyńskiego i dominium Nawojowej.

16 Podobnie wykonywano kary śmierci w sądzie grodzkim Sanoku (por. O. B a l zer, Regestr zloczyńców grodu sanockiego 1554-1638 r., Lwów 1891, indeks, hasło: kara, s. 251-252. Znacznie surowszy był natomiast sąd $\mathrm{w}$ Muszynie, który orzekał też spalenie na stosie, wbicie na pal, wplecenie w koło (Akta Sądu kryminalnego Kresu Muszyńskiego 1647-1765), wyd. F. Piekosiński, [w:] Starodawne prawa polskiego pomniki, t. IX, Kraków 1889, s. 321 i n.

${ }^{17}$ K. Tetmajer, Na skalnym Podhalu, Kraków 1955, s. 258 i n.: opowiadanie o Dobku Jaworcarzu.

${ }^{18} \mathrm{~S}$. Grodziski, Historia ustroju spoleczno-politycznego Galicji 1772-1848, Wroctaw 1971, s. $199-200$.

${ }^{19}$ Miał on w owym czasie dobrą obsadę prawniczą. Jednym z sẹdziów wiśnickich był Michał Kossak - ojciec malarza Juliusza. 
szerzając naszą wiedzę w zakresie prawa i procesu karnego w XVII w. Obszerne, nieraz bardzo szczegółowe protokoły pozwalają śledzić tok procesu: od oskarżenia, które wnosił instygator (nie powstała w Wiśniczu instytucja „rugowników”) - przez postępowanie dowodowe - aż po wyrok i jego wykonanie. Wydawnictwo ilustruje nam działalność lokalnego sądu miejskiego, wójtowsko-radzicckiego, o wielkim jednak znaczeniu i szerokim zasięgu terytorialnym. Jest też rzeczą wskazaną, aby Wydawca podjął trud opracowania i opublikowania dalszego tomu czarnej ksiegi wiśnickiej ${ }^{20}$. Należałoby też przebadać cywilnoprawną działalność tego sądu, gdyż i po niej pozostała nieprzebadana jeszcze dokumentacja ${ }^{21}$. Zachowały się wreszcie akta tego sądu $\mathrm{z}$ czasów po zaborze, ale te już powstawały na podstawie prawa austriackiego.

${ }^{20}$ Por. wyżej tekst i przyp. 10.

${ }^{21}$ Por. wyżej tekst i przyp. 9. 
